\title{
VITAMIN C BERPENGARUH DALAM MEMPERBAIKI KERUSAKAN HEPAR AKIBAT PEMBERIAN MONOSODIUM GLUTAMAT
}

\author{
Mutiara Khalish*, Lathifah Yasmine Wulandari \\ Program Studi Pendidikan Dokter Universitas Lampung,Jl. Prof. Dr. Ir. Sumantri Brojonegoro No.1, \\ GedongMeneng, Kec. Rajabasa, Kota Bandar Lampung, Lampung, Indonesia 35145 \\ *khalishmutiara25@gmail.com (+6282360605178)
}

Konsumsi monosodium glutamat dalam jumlah berlebih dapat menyebabkan dampak berkaitan dengan kerusakan hepar yang ditandai adanya peningkatan kadar enzim aspartate transaminase dan alanine transaminase. Vitamin c berperan menjaga sistem imunitas tubuh dan mempercepat proses penyembuhan kerusakan hepar. Tujuan penulisan artikel ini adalah untuk mengetahui manfaat vitamin c sebagai upaya dalam memperbaiki kerusakan hepar akibat monosodium glutamat. Metode yang digunakan dalam artikel ini adalah penelusuran artikel melalui database Google Scholar, NCBI dan Elsevier. Tahun penerbitan pustaka adalah dari tahun 2010 hingga 2019 dengan 17 sumber pustaka. Hasil dari literatur review ini menunjukan bahwa vitamin c dapat mengurangi kerusakan hepar akibat monosodium glutamat dengan adanya penurunan kadar enzim aspartate transaminase dan alanine transaminase. Vitamin c dapat digunakan untuk melawan efek radikal bebas dari monosodium glutamat karena aktifitasnya sebagai antioksidan. Vitamin c berpengaruh dalam memperbaiki kerusakan hepar akibat pemberian monosodium glutamat.

Kata kunci: aspartate transaminase, alanine transaminase, monosodium glutamat, vitamin c

\section{VITAMIN C AFFECT IN IMPROVING HEPAR DAMAGE CAUSED BY ADMINISTRATION OF MONOSODIUM GLUTAMATE}

\begin{abstract}
Excessive consumption of monosodium glutamate can cause effects related to liver damage which is marked by an increase in levels of the enzymes aspartate transaminase and alanine transaminase. Vitamin c plays a role in maintaining the body's immune system and accelerating the healing process of liver damage. The purpose of writing this article is to determine the benefits of vitamin $c$ as an effort to repair liver damage due to monosodium glutamate. The method used in this article is article searching through Google Scholar, NCBI and Elsevier databases. The year of library publication is from 2010 to 2019 with 17 library sources. The results of this review literature show that vitamin $c$ can reduce liver damage due to monosodium glutamate by decreasing levels of the enzymes aspartate transaminase and alanine transaminase. Vitamin $C$ can be used to fight the effects of free radicals from monosodium glutamate because of its activity as an antioxidant. Vitamin $C$ has an effect on repairing liver damage due to monosodium glutamate.
\end{abstract}

Keywords: aspartate transaminase, alanine transaminase, monosodium glutamate, vitamin $c$

PENDAHULUAN

Perkembangan zaman yang diikuti juga dengan perubahan gaya hidup menyebabkan terjadinya perubahan pola konsumsi makanan salah satunya konsumsi makanan cepat saji. Sebagian makanan tersebut mengandung Monosodium Glutamate (MSG) yang berfungsi untuk menambah rasa lezat atau umami dalam makanan. MSG adalah garam natrium yang berikatan dengan asam amino berupa asam 
glutamat (Lioe, Selamat, and Yasuda 2010). Asam glutamat yang terdapat pada protein hanya terdapat dalam bentuk L-Glutamic acid, sedangkan asam glutamat dalam bentuk $D$ Glutamic acid tidak digunakan pada organisme tingkat tinggi dikarenakan asam glutamat dalam bentuk $D$ Glutamic acid hanya dapat dipergunakan oleh organisme tingkat rendah seperti beberapa jenis bakteri yang memiliki fungsi sebagai penyusun dinding sel bakteri tersebut (He et al. 2011).

Konsumsi MSG dalam jumlah yang melebihi anjuran akan memberikan dampak buruk terhadap tubuh.Penelitian menunjukan bahwa MSG dapat menyebabkan peningkatan kadar AST dan ALT yang menggambarkan kerusakan sel hepar (Inyang, Ojewunmi, and Ebuehi 2012). MSG dapat menimbulkan kerusakan permeabilitas seluler, homeostasis seluler dan mempengaruhi integritas seluler yang mengakibatkan terjadinya toksisitas terhadap sel hepar (Eweka, Om'Iniabohs, and Adjene 2011).

Vitamin $\mathrm{C}$ adalah salah satu antioksidan yang larut dalam air. Vitamin $\mathrm{C}$ berperan dalam menjaga sistem imunitas tubuh dan mempercepat proses penyembuhan (Kembuan, Wangko, and Tanudjaja 2013). Vitamin C atau asam askorbat berperan sebagai antioksidan yang dapat langsung bereaksi dengan anion superoksida, radikal hidroksil, oksigen singlet dan lipid peroksida. Asam askorbat juga berperan sebagai reduktor yang akan mendonorkan satu elektron membentuk semi dehidroaskorbat atau radikal ascorbyl yang bersifat tidak reaktif dan selanjutnya mengalami reaksi disproporsionasi membentuk dehidroaskorbat yang bersifat tidak stabil .

Berdasarkan hal tersebut, maka pemberian vitamin $\mathrm{C}$ perlu dilakukan studi literatur mengenai manfaatnya dalam memperbaiki kerusakan hepar akibat MSG. Literatur review ini dilakukan untuk mengetahui manfaat vitamin $\mathrm{C}$ sebagai upaya dalam memperbaiki kerusakan hepar akibat MSG.

\section{METODE}

Penulisan ini menggunakan metode literatur review. Sumber pustaka yang digunakan dalam artikel ini melibatkan 17 pustaka yang berasal dari jurnal nasional atau internasional, maupun website. Penelusuran sumber pustaka dalam artikel ini melalui database Google Scholar, NCBI, Elsevier dengan kata kunci Aspartate Transaminase, Alanine Transaminase, Monosodium Glutamate, Vitamin C. Tahun penerbitan sumber pustaka dalam penulisan artikel ini adalah 2010-2019.

\section{HASIL}

Pemberian vitamin C sejumlah 300 $\mathrm{mg} / \mathrm{kgBB}$ dan vitamin E sejumlah 200 $\mathrm{mg} / \mathrm{kgBB}$ terhadap tikus yang diinduksi MSG selama 14 hari secara signifikan terjadi penurunan kadar AST dan ALT (Tawfik and Al-Badr 2012). Pemberian vitamin C sejumlah $100 \mathrm{mg} / \mathrm{kgBB}$ terhadap tikus yang diinduksi MSG selama 14 hari dapat mengurangi kerusakan hati dengan adanya penurunan kadar AST dan ALT pada hepar tikus (Ibrahim et al. 2011).

Penelitian lain juga menunjukan bahwa pemberian vitamin $\mathrm{C}$ sejumlah 500 $\mathrm{mg} / \mathrm{kgBB}$ terhadap tikus yang diinduksi MSG selama 45 hari menunjukkan perbaikan hati yang rusak dengan adanya penurunan kadar AST dan ALT 
setelah pengobatan dengan vitamin $\mathrm{C}$ (El-Meghawry EL-Kenawy, Osman, and Daghestani 2013).

\section{PEMBAHASAN}

Monosodium glutamat adalah hasil dari purifikasi glutamat atau gabungan dari beberapa asam amino dengan sejumlah kecil peptida yang dihasilkan dari proses Hydrolized Vegetable Protein (HVP). Asam glutamat merupakan salah satu dari asam amino yang terdapat dalam dua bentuk, yaitu bentuk L-Glutamic acid dan D-Glutamic acid. Asam glutamat yang terdapat pada protein hanya terdapat dalam bentuk $L$ Glutamic acid, sedangkan asam glutamat dalam bentuk D-Glutamic acid tidak digunakan pada organisme tingkat tinggi dikarenakan asam glutamat dalam bentuk D-Glutamic acid hanya dapat dipergunakan oleh organisme tingkat rendah seperti beberapa jenis bakteri yang memiliki fungsi sebagai penyusun dinding sel bakteri tersebut (He et al. 2011).

Monosodium glutamate dapat terurai dengan mudah dan menghasilkan glutamat bebas. Proses deaminasi glutamat menghasilkan ion amonium $\left(\mathrm{NH} 4^{+}\right)$yang beracun kecuali didetoksifikasi di hati melalui proses siklus urea. Kelebihan ion amonium yang terjadi karena meningkatnya kadar glutamat setelah konsumsi MSG yang berdampak kerusakan terhadap sel hepar.

Kemungkinan kelebihan ion amonium merusak mitokondria melalui aktifasi jalur $\mathrm{Ca}^{2+}$ independen apoptosis intrinsik (Inyang et al. 2012). Pemberian MSG dapat menimbulkan efek parasimpatik yang akan melepaskan asetilkolin ke dalam darah sehingga kolinesterase meningkat dalam plasma dan merusak jaringan hati.
Penggunaan MSG terus menerus akan menyebabkan terjadinya akumulasi MSG dalam hepar.

Aspartate aminotransferase adalah enzim hepar yang membantu produksi protein. Enzim ini mengkatalisa transfer suatu gugus amino dari aspartat ke $\quad \alpha$-ketoglutarat menghasilkan oksaloasetat dan glutamat. Enzim ini juga ditemukan pada organ lain seperti jantung, otot rangka, otak dan ginjal. Kerusakan pada salah satu dari beberapa organ tersebut bisa menyebabkan peningkatan kadar pada enzim dalam darah. Kadar normal ada pada kisaran 7-40 U/L. Enzim ini juga membantu dalam mendeteksi nekrosis sel hepar, tetapi dianggap penanda yang kurang spesifik untuk kerusakan sel hepar sebab enzim ini juga bisa menggambarkan kelainan pada jantung, otot rangka, otak, dan ginjal. Rasio serum AST dengan ALT bisa digunakan untuk membedakan kerusakan hepar dari kerusakan organ lain (Singh, Bhat, and P Sharma 2011).

Alanine aminotransferase adalah penanda yang paling sering digunakan pada toksisitas hepar. Alanine aminotransferase merupakan suatu enzim hepar yang berperan penting dalam metabolisme asam amino dan glukoneogenesis. Enzim ini mengkatalisa pemindahan suatu gugus amino dari alanin ke $\alpha$-ketoglutarat untuk menghasilkan glutamat dan piruvat dengan kadar normal berada pada kisaran 5-10 U/L. Peningkatan kadar enzim terjadi pada kerusakan hepar. Pengukuran kadar enzim ini merupakan tes yang lebih spesifik untuk mendeteksi kelainan hepar karena terutama ditemukan dalam hepar (Singh et al. 2011). 
Hepar merupakan organ yang berfungsi menawarkan zat-zat toksik yang masuk kedalam tubuh, sehingga akumulasi yang terjadi dapat menyebabkan kerusakan sel hepar akibat efek radikal bebas yang ditimbulkan oleh MSG tersebut (Kanti, 2012). Pada penelitian lain didapatkan bahwa terjadi penurunan antioksidan pada hati seperti glutathion, katalase, dan superoxide dismutase pada tikus yang diberi MSG. Selain itu, pemberian MSG pada tikus juga memperlihatkan adanya stres oksidatif yang ditandai dengan adanya peroksidasi lemak, peningkatan aktivitas glutathione-s-transferase (Husarova \& tatnikova 2013).

Penelitian menunjukan bahwa pemberian MSG sebanyak $4 \mathrm{~g} / \mathrm{kgBB}$ dan $8 \mathrm{~g} / \mathrm{kgBB}$ tikus Wistar dewasa selama 28 hari menyebabkan peningkatan kadar AST dan ALT yang menggambarkan kerusakan sel hepar (Inyang et al. 2012). Penelitian yang dilakukan terhadap tikus yang diinduksi MSG dosis $4 \mathrm{~g} / \mathrm{kg}$ BB selama 7 hari menunjukan peningkatan secara signifikan pada kadar serum AST dan ALT (Eid et al. 2019). Penelitian lainnya juga menunjukan bahwa tikus putih (Rattus norvegius) galur Wistar yang diinduksi $7 \mathrm{~g} / \mathrm{kgBB}$ MSG selama 14 hari mengakibatkan peningkatan kadar serum glutamat oksaloasetat transaminase (SGOT) dan serum glutamat piruvat transaminase (SGPT) (Wahyudi, Bahar, and Septianawati 2018).

Vitamin $\mathrm{C}$ atau asam askorbat adalah vitamin yang larut dalam air berfungsi memberikan perlindungan antioksidan plasma lipid dan diperlukan untuk fungsi kekebalan tubuh termasuk (leukosit, fagositosis dan kemotaksis), penekanan replikasi virus dan produksi interferon (Mitmesser et al. 2016).
Vitamin $\mathrm{C}$ merupakan senyawa organik yang tidak dapat disintesis oleh tubuh dan dibutuhkan dalam jumlah sedikit sehingga harus diperoleh dari makanan (Daryono et al., 2016) dan paling labil karena mudah rusak oleh adanya kontak dengan udara, panas, dan logam. Vitamin $\mathrm{C}$ bermanfaat sebagai koenzim dan antioksidan yang efektif mengatasi radikal bebas di dalam tubuh (Rezvani, Moradi, and Soltani 2013).

Vitamin C dapat digunakan untuk melawan efek radikal bebas dari MSG karena aktifitasnya sebagai antioksidan. Vitamin C merupakan antioksidan yang dapat menangkal efek radikal bebasyang terjadi pada hepar akibat Monosodium Glutammate (Kanti 2012). Vitamin C memiliki sifat sebagai pelindung hati dengan memperbaiki level Alanine aminotransferase (ALT), Aspartate aminotransferase (AST) pada hati yang terpapar zat hepatotoksik karena sifat antioksidannya. Antioksidan dalam vitamin C dapat langsung bereaksi dengan anion superoksida, radikal hidroksil, oksigen singlet dan lipid peroksida (Bashandy and Alwasel 2011).

Asam askorbat juga berperan sebagai reduktor yang akan mendonorkan satu elektron membentuk semi dehidroaskorbat atau radikal ascorbyl yang bersifat tidak reaktif dan selanjutnya mengalami reaksi disproporsionasi membentuk dehidroaskorbat yang bersifat tidak stabil. Dehidroaskorbat akan terdegradasi membentuk asam oksalat dan asam treonat. Oleh karena kemampuan vitamin $\mathrm{C}$ sebagai penghambat radikal bebas, maka peranannya sangat penting dalam menjaga integritas membran sel (Rezvani et al. 2013). 


\section{SIMPULAN}

Vitamin C memiliki antioksidan yang dapat menangkal radikal bebas sehingga vitamin $\mathrm{C}$ berpengaruh dalam memperbaiki kerusakan hepar akibat pemberian monosodium glutamat.

\section{DAFTAR PUSTAKA}

Bashandy, S. A., and S. H. AlWasel. 2011. "Carbon TetrachlorideInduced Hepatotoxicity and Nephrotoxicity in Rats: Protective Role of Vitamin C." Journal of Pharmacology and Toxicology 6(3):283-92.

Eid, Refaat A., Mubarak Al-Shraim, Mohamed Sa Zaki, Samaa S. Kamar, Noha S. Abdel Latif, Sally Negm, Bahjat Al-Ani, and Mohamed A. Haidara. 2019. "Vitamin E Protects against Monosodium GlutamateInduced Acute Liver Injury and Hepatocyte Ultrastructural Alterations in Rats." Ultrastructural Pathology 43(45):199-208.

El-Meghawry EL-Kenawy, Ayman, Hosam Eldin Hussein Osman, and Maha Hasan Daghestani. 2013. "The Effect of Vitamin C Administration on Monosodium Glutamate Induced Liver Injury. An Experimental Study." Experimental and Toxicologic Pathology 65(5):513-21.

Eweka, AO, FAE Om'Iniabohs, and JO Adjene. 2011. "Histological Studies Of The Effects Of Monosodium Glutamate On The Stomach Of Adult Wistar Rats." Annals of Biomedical Sciences 1(1):21-30.

He, Ka, Shufa Du, Pengcheng Xun, Sangita Sharma, Huijun Wang,
Fengying Zhai, and Barry Popkin. 2011. "Consumption of Monosodium Glutamate in Relation to Incidence of Overweight in Chinese Adults: China Health and Nutrition Survey (CHNS)." American Journal of Clinical Nutrition 93(6):1328-36.

Husarova, Veronika, and Daniela Ostatnikova. 2013. "Monosodium Glutamate Toxic Effects and Their Implications for Human Intake: A Review." JMED Research 2013:1-12.

Ibrahim, Mohammed Auwal, Ganiyat O. Buhari, Abubakar B. Aliyu, Isa Yunusa, and Mohammed Bisalla. 2011. "Amelioration of Monosodium GlutamateInduced Hepatotoxicity by Vitamin C." European Journal of Scientific Research 60(1):159-65.

Inyang, B., O. Ojewunmi, and $\mathrm{O}$. Ebuehi. 2012. "Toxicological Effects of Monosodium Glutamate on the Liver Enzyme Markers and Lipid Profile of Adult Wistar Rats." Asian Journal of Biochemical and Pharmaceutical Research 2(3):266-73.

Kanti, Eka Aprilia Arum. 2012. "Pengaruh Pemberian Vitamin C Terhadap Gambaran Histologis Hepar Mencit Jantan Dewasa (Mus Musculus L) Yang Diinduksi Monosodium Glutammate." Medical Journal of Lampung University 1(1):8195.

Kembuan, Melisa Veronica, Sunny Wangko, and George N. Tanudjaja. 2013. "Peran 
Vitamin C Terhadap Pigmentasi Kulit." Jurnal Biomedik (Jbm) 4(3).

Lioe, Hanifah Nuryani, Jinap Selamat, and Masaaki Yasuda. 2010. "Soy Sauce and Its Umami Taste: A Link from the Past to Current Situation." Journal of Food Science 75(3).

Mitmesser, Susan H., Qian Ye, Mal Evans, and Maile Combs. 2016. "Determination of Plasma and Leukocyte Vitamin C Concentrations in a Randomized, Double-Blind, Placebo-Controlled Trial with Ester-C®.” SpringerPlus 5(1).

Rezvani, H. T., P. Moradi, and F. Soltani. 2013. "The Effect of Nitrogen Fixation and Phosphorus Solvent Bacteria on Growth Physiology and Vitamin C Content of Capsicum Annum L." Iranian J. Plant Physiol 3(2):673-82.

Setiadi Daryono, Budi, Sigit Dwi Maryanto, Sholihatun Nissa, and Ganies Riza Aristya. 2016.
"Analisis Kandungan Vitamin Pada Melon (Cucumis Melo L.) Kultivar Melodi Gama 1 Dan Melon Komersial." Biogenesis: Jurnal Ilmiah Biologi 4(1):1-9.

Singh, Anita, Tej K. Bhat, and Om P Sharma. 2011. "Clinical Biochemistry of Hepatotoxicity." Journal of Clinical Toxicology 04(01):119.

Tawfik, Manal Said, and Nawal AlBadr. 2012. "Adverse Effects of Monosodium Glutamate on Liver and Kidney Functions in Adult Rats and Potential Protective Effect of Vitamins C and E." Food and Nutrition Sciences 03(05):651-59.

Wahyudi, Agung, Yenni Bahar, and Paramita Septianawati. 2018. "Pengaruh Ekstrak Etanol Daun Kemangi ( Ocimum Basilicum L Folium ) Terhadap Kadar Sgot Dan Sgpt Tikus Putih (Rattus Norvegicus Strain Wistar) Yang Diinduksi Msg." Herb-Medicine Journal 1(1):30-39. 